\title{
Synthesis of bicyclic lactams using novel Schmidt reactions
}

\author{
Mike Casey,* John A. Donnelly, Joseph C. Ryan, and Satoshi Ushioda \\ Chemistry Department, the Centre for Synthesis and Chemical Biology, and the Conway Institute \\ of Biomolecular and Biomedical Research, University College Dublin, Dublin 4, Ireland \\ E-mail:mike.casey@ucd.ie
}

\section{Dedicated to Professor Tony McKervey on the occasion of his retirement from Queen's University, Belfast}

(received 10 Mar 03; accepted 29 Jun 03; published on the web 03 Jul 03)

\begin{abstract}
Several $\gamma, \delta$-unsaturated $\beta$-diketones were prepared by acylation of the lithium enolates of cyclic ketones by cinnamoyl chlorides. Reaction of the cinnamoylcyclohexanones with 2 equivalents of hydrazoic acid in sulfuric acid gave bicyclic lactams in good yields. The mechanism of this process involves a Schmidt reaction, followed by addition of $\mathrm{HN}_{3}$ to the enone, migration of the aryl group onto nitrogen, and a cyclisation in which the arylamino group is displaced by the amide nitrogen. The scope of the reaction is limited to the preparation of 7-5 bicyclic systems from enoyl cyclohexanones, other precursors gave dihydropyrones or complex mixtures.
\end{abstract}

Keywords: Acylation, diketones, enones, Schmidt, lactams, alkaloids

\section{Introduction}

The reaction of carbonyl compounds with hydrazoic acid, known as the Schmidt reaction, is a convenient method for the synthesis of a wide variety of nitrogen containing materials. ${ }^{1}$ It has the advantages of simplicity, ready availability of reactants, mild reaction conditions, and good functional group tolerance. The reaction of cyclic ketones to give lactams is a particularly useful application, and many examples are known. In recent times, this method has been extended to provide access to some $N$-substituted lactams by replacing hydrazoic acid with organic azides. ${ }^{2}$ A notable development, that greatly extends the power of the reaction, has been the discovery that the intramolecular Schmidt reaction of organic azides with ketones (Scheme 1), ${ }^{3}$ or with carbocations derived from alkenes or alcohols, ${ }^{4}$ can give a wide range of bicyclic products bearing nitrogen at one of the ring fusion positions. Such ring systems are core structures in a wide variety of alkaloids. The work of Aubé provides an impressive demonstration of the synthetic utility of this intramolecular variant. ${ }^{5}$ 
${ }^{\S}$ Deceased $27^{\text {th }}$ June 1991.
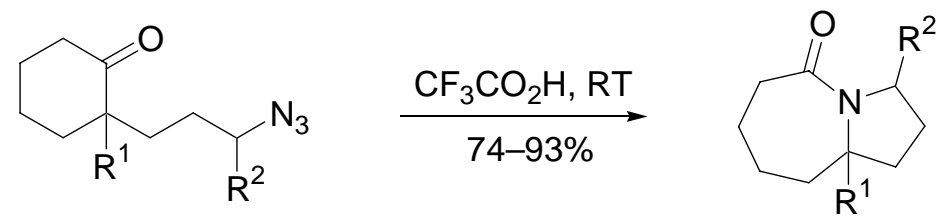

\section{Scheme 1}

The acid-catalysed reaction of hydrazoic acid with $\alpha, \beta$-unsaturated ketones is less widely used. A systematic investigation by Boyer established that alkenes with conjugated electronwithdrawing groups readily undergo addition reactions with hydrazoic acid. ${ }^{6}$ It is noteworthy that cinnamoyl derivatives, in which the conjugation is extended into a benzene ring, do not generally react with hydrazoic acid. ${ }^{6,7}$ However, the presence of a strongly electron-withdrawing substituent, e.g. 4-nitro, on the aryl group restores the reactivity. In these reactions the use of strongly acidic conditions is unsuitable if the azide adduct is to be isolated. The azide may decompose by a Schmidt-type reaction with loss of nitrogen, e.g. the sulfuric acid catalysed decomposition of 4-azido-4-p-nitrophenylbutan-2-one 1 to give enaminone $\mathbf{2}$ (Scheme 2). ${ }^{8}$

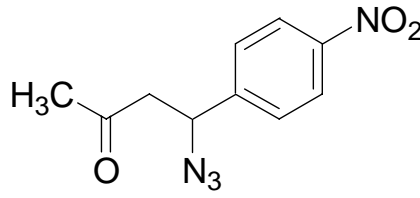

1

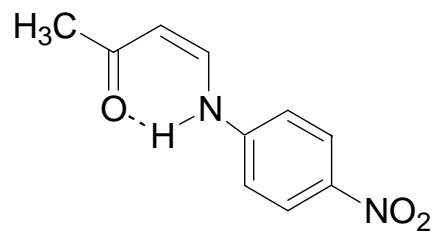

2

\section{Scheme 2}

As a continuation of the investigation into the chemistry of the $\alpha, \beta$-unsaturated 1,3-diketone moiety undertaken in this laboratory, ${ }^{9}$ it was decided to study the Schmidt reaction of cinnamoyl cyclohexanone 3. It was thought incorporation of a nitrogen atom into the saturated ring or the side chain, followed by cyclisations, might constitute an entry into oxygen and nitrogen heterobicyclic systems. We now report that reaction of $\alpha, \beta$-unsaturated 1,3 -diketones, such as 3 , with hydrazoic acid produces bicyclic lactams via an unexpected sequence of reactions that includes two Schmidt processes.

\section{Results and Discussion}

\section{Preparation of $\gamma, \delta$-unsaturated $\beta$-diketones}

The $\gamma, \delta$-unsaturated $\beta$-diketones required for this work were prepared by reaction of ketone enolates with enoyl chlorides. The acylation of enolates is a somewhat unpredictable process, and the yield and selectivity for $C$-acylation versus $O$-acylation depend on the ketone, and on the 
acylating agent used. ${ }^{10}$ The synthesis of cinnamoylcyclohexanone 3 in this way was described by Linn and Hauser. ${ }^{11}$ Sodium amide was prepared in situ by the reaction of sodium with liquid ammonia, and the excess ammonia was removed and replaced by dry diethyl ether before adding the cyclohexanone. Reaction of the enolate (3 molar equivalents were used to prevent diacylation) with cinnamoyl chloride at $0{ }^{\circ} \mathrm{C}$ gave the cinnamoylcyclohexanone 3 in $40 \%$ yield. Subsequently, Sheehy used commercial $\mathrm{NaNH}_{2}$, in ether, ${ }^{9}$ and removed the ammonia generated in the formation of the enolate by passing a stream of nitrogen through the reaction mixture, thus reducing the possibility of cinnamide formation. Difficulties in isolating product $\mathbf{3}$ were eased by removing the excess cyclohexanone with aqueous sodium metabisulfite. These measures increased the yield to $60 \%$. In the present work the method of Sheehy was employed, but the reaction temperature was reduced from $0{ }^{\circ} \mathrm{C}$ to $-78{ }^{\circ} \mathrm{C}$, and it was found that the yield of cinnamoylcyclohexanone $\mathbf{3}$ increased to 75\%, and the 4-methoxy and 4-nitro analogues 4 and 5 were obtained in 60\% and 15\% yields, respectively (Scheme 3 ).
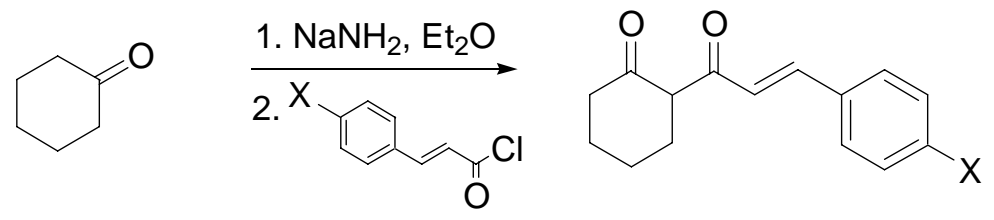

$$
\begin{aligned}
& 3 X=\mathrm{H} \\
& 4 X=\mathrm{OMe} \\
& 5 X=\mathrm{NO}_{2}
\end{aligned}
$$

\section{Scheme 3}

As expected, ${ }^{12}$ attempted synthesis of cinnamoylcyclopentanone by the above method failed. However, deprotonation of cyclopentanone using LDA in THF at $-78{ }^{\circ} \mathrm{C}$, and reaction with cinnamoyl chloride (0.3 eq. to prevent diacylation) at $-78{ }^{\circ} \mathrm{C}$ gave cinnamoylcyclopentanone 6 in 83\% yield. A number of other $\alpha, \beta$-unsaturated 1,3-diketones were prepared in good yields (based on acyl chloride) by this method (Scheme 4). Clean $C$-acylation was observed in all cases. The reaction of lithium enolates with acyl chlorides has been found to give $C$-acylation in most, but not all, cases. ${ }^{13}$ Improvements in acylation methodology have been reported since the completion of this work, ${ }^{14}$ so it is likely that our procedure could be improved upon.
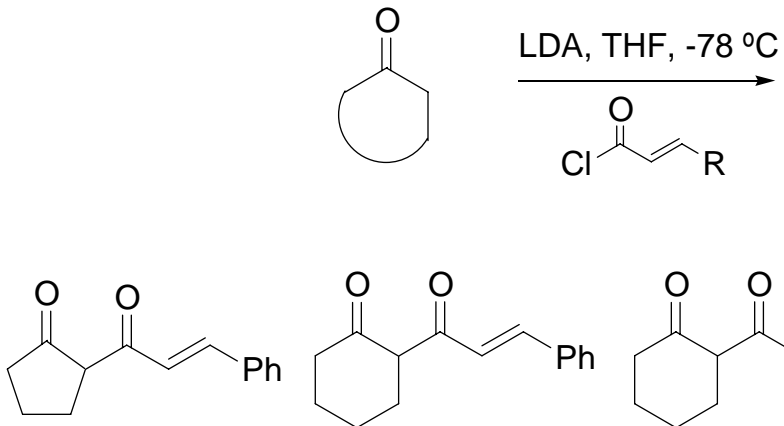

6, 83\%<smiles>O=C(/C=C/c1ccccc1)C1CCCCC1=O</smiles>

3, $86 \%$<smiles>CC=CC(=O)C1CCCCC1=O</smiles>

7, $81 \%$<smiles>[R]C=CC(=O)C1CCCCC1=O</smiles>

3, 6-9
9, $88 \%$<smiles>O=C(/C=C/c1ccccc1)C1CCc2ccccc2C1=O</smiles>

8, $82 \%$ 


\section{Scheme 4}

The ${ }^{1} \mathrm{H}$ NMR spectrum of 3 contained a one-proton singlet, exchangeable with $\mathrm{D}_{2} \mathrm{O}$, at $\delta 16.83$, a position typical of the hydroxy group in a keto-enol system that is stabilised by intramolecular hydrogen bonding. Clearly it existed in one of the two possible enol forms 3a and 3b (Figure 1).

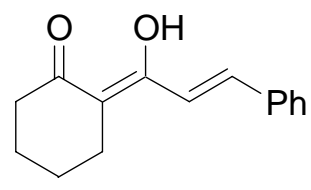

$3 a$

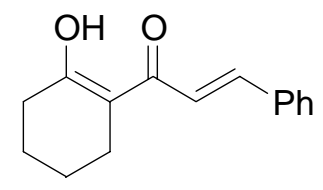

$3 b$

\section{Figure 1}

The observed ${ }^{13} \mathrm{C}$ NMR chemical shifts were $\delta 193.4$ for the carbonyl carbon and $\delta 180.1$ for the enolic carbon. The predicted values, using the method of additive shift parameters, for enol 3a were 196 and 177 ppm, respectively, whereas the values for enol $\mathbf{3 b}$ were predicted to be 180 and 163 ppm, respectively. The observed chemical shifts were much closer to those predicted for isomer 3a, suggesting that this is the predominant enol form. More conclusive proof was obtained from a carbon-hydrogen correlation spectrum, optimised for long range coupling (COLOC), which showed strong cross peaks between (i) the carbonyl carbon at $\delta 193.4$ and the $8 \mathrm{H}$ multiplet at $\delta 1.74-2.60\left(\mathrm{CH}_{2} \times 4\right)$, (ii) the 2'-olefinic carbon at $\delta 107.3$ and the enolic $\mathrm{OH}$ singlet at $\delta 16.8$, and (iii) the enolic carbon at $\delta 180.1$ and the 2'-olefinic hydrogen doublet at $\delta$ 7.0. As the ${ }^{13} \mathrm{C}$ peaks at $\delta 193.4$ and $\delta 180.1$ can be unambiguously assigned to the keto and enol carbons, respectively, the COLOC correlations are then consistent with the structure possessing the exocyclic double bond $\mathbf{3 a}$ and not the alternative enol $\mathbf{3 b}$. In these $\alpha, \beta$ unsaturated 1,3-diketo systems the exocyclic enol form is considerably stabilised by the extended conjugation. The same tautomer probably predominates in the case of the cyclopentanone and cycloheptanone derivatives $\mathbf{6}$ and $\mathbf{8}$ also, judging by the observation of long-range coupling between the 2'-olefinic hydrogen and the enolic $\mathrm{OH}$ proton in both cases.

During the course of the study of the reactions of some of the $\alpha, \beta$-unsaturated-1,3-diketones prepared in the previous sections, it was found necessary to block the enolisation by the incorporation of an alkyl group between the two keto functions. The major difficulty in alkylating 1,3-dicarbonyl compounds is that both $C$ - and $O$-alkylation can occur. When the equilibrium concentration of the enol tautomer is high, such as in 1,3-diketones, predominant $O$ alkylation is observed. ${ }^{15}$ Clarke and Miller reported a very useful method for selective mono- $C$ alkylation of a number of 1,3-dicarbonyl compounds, using alkyl iodides and tetraalkylammonium fluorides, under mild conditions. ${ }^{16}$ In a simple adaptation of Miller's method, three molar equivalents of tetrabutylammonium fluoride (as a solution in THF) were added to cinnamoylcyclohexanone 3 at $0{ }^{\circ} \mathrm{C}$ and the solvent was removed under reduced pressure, yielding an orange solid which was dissolved in dry dichloromethane before addition of 
four molar equivalents of iodomethane. The $C$-alkylated product $\mathbf{1 0}$ was obtained in $87 \%$ yield (Scheme 5). Similarly, 2-cinnamoyl- $\alpha$-tetralone $\mathbf{9}$ gave the methylated product $\mathbf{1 1}$ in $80 \%$ yield.<smiles>O=C(/C=C/c1ccccc1)C1CCCCC1=O</smiles>

3<smiles>O=C(/C=C/c1ccccc1)C1CCc2ccccc2C1=O</smiles>

9

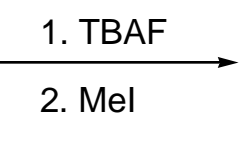

$\underset{\text { 2. } \mathrm{Mel}}{\stackrel{\text { TBAF }}{\longrightarrow}}$<smiles>CC1(C(=O)/C=C/c2ccccc2)CCCCC1=O</smiles>

10

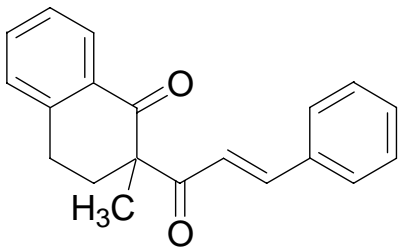

11

\section{Scheme 5}

\section{The reaction of cinnamoyl cyclohexanones with hydrazoic acid}

The Schmidt reaction may be catalysed by a variety of protic and aprotic acids, of which sulfuric acid is the most extensively used. The room temperature reaction of cinnamoyl cyclohexanone with one equivalent of sodium azide, using concentrated sulfuric acid as the catalyst and reaction medium, resulted in a mixture of products (Scheme 6).

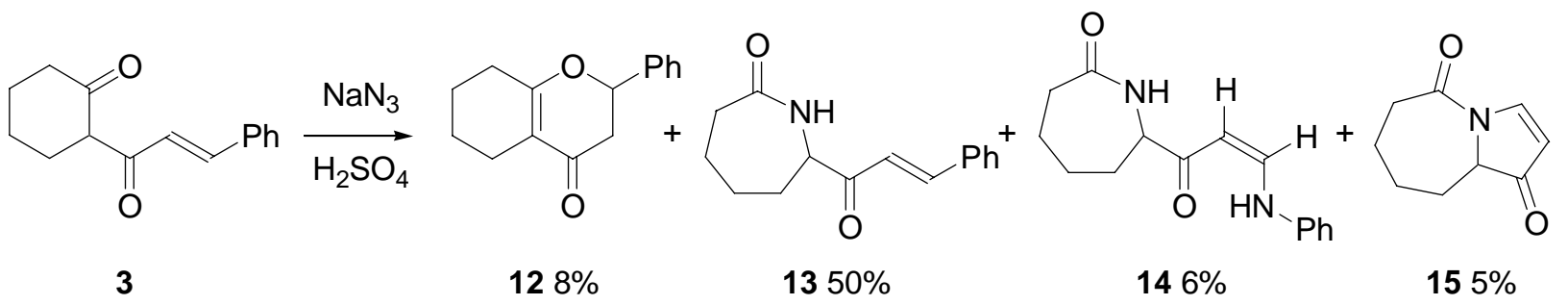

\section{Scheme 6}

The dihydropyranone 12, resulting from the acid catalysed cyclisation of the starting ketone, was isolated in $8 \%$ yield. Cyclisations of $\alpha, \beta$-unsaturated 1,3 -diketones under acidic conditions have been reported previously. ${ }^{17}$ Indeed, the dihydropyrone 12 can be obtained in $80 \%$ yield by heating cinnamoylcyclohexanone in acetic acid for $8 \mathrm{~h}$. The major product (50\% yield) was identified as 7-(3-phenylprop-2-enoyl)hexahydro-2-azepinone $\mathbf{1 3}$ resulting from attack of the hydrazoic acid on the ring ketone followed by migration of the more substituted bond. The cyclohexanone carbonyl is expected to be more reactive than the side-chain carbonyl whose reactivity is diminished by conjugation. It was evident from the spectroscopic data that the product was the $\alpha$-amido ketone $\mathbf{1 3}$ and not the isomer resulting from migration of the less substituted bond, in agreement with the results reported for other 2-substituted cyclohexanones. ${ }^{18}$ 
A third product, isolated in $6 \%$ yield, was shown to have molecular formula $\mathrm{C}_{15} \mathrm{H}_{18} \mathrm{~N}_{2} \mathrm{O}_{2}$, corresponding to the addition of another $\mathrm{NH}$ group to the lactam 13. The ${ }^{1} \mathrm{H}$ NMR spectrum showed a doublet for an alkene hydrogen at $\delta 5.27$ with a coupling constant of $8.2 \mathrm{~Hz}$. The second alkene proton appeared as a double doublet at $\delta 7.40$, coupled both with the $\alpha-\mathrm{H}$ and a second proton which appeared as a broad doublet at $\delta 11.30$ with a coupling constant of $12.9 \mathrm{~Hz}$. The IR spectrum showed two carbonyl bands, one at $1649 \mathrm{~cm}^{-1}$, the other at the exceptionally low value of $1606 \mathrm{~cm}^{-1}$. On this basis, the structure was assigned as the enaminone 14, resulting from the addition of hydrazoic acid to the $\beta$-position of the $\alpha, \beta$-unsaturated system followed by migration of the phenyl group (Scheme 7). Migration of the aryl group on treatment of benzyl azides with acids is well precedented (e.g. Scheme 2). ${ }^{8,19}$ The enaminone derivative $\mathbf{1 4}$ has a cisconfiguration due to intramolecular hydrogen bonding between the $\mathrm{NH}$ and the carbonyl. This accounts for the low $\mathrm{J}_{2 ' 3^{\prime}}$ coupling constant, and the low carbonyl stretching frequency. As pointed our earlier, addition of hydrazoic acid to the aryl enone was not expected. The unexpected reactivity may be a result of the inductive effect of the ring amide, which may be protonated under the strongly acidic reaction conditions.

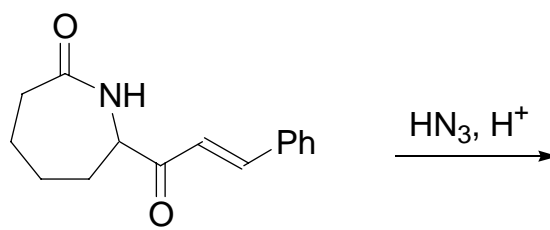

13
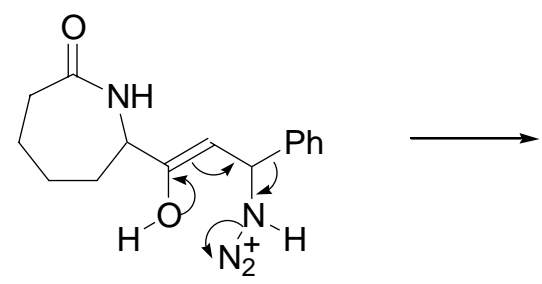

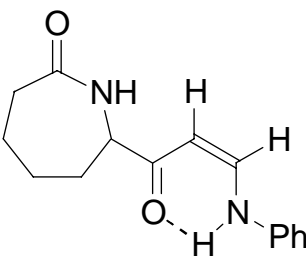

14

\section{Scheme 7}

The final product, isolated in 5\% yield, was identified as lactam 15. The ${ }^{1} \mathrm{H}$ NMR spectrum contained a pair of doublets at $\delta 5.72$ and $\delta 8.71$, assigned to $\mathrm{H}-9$ and $\mathrm{H}-10$, respectively, with $\mathrm{H}-$ 7 observed as double doublet at $\delta 3.92$. The unusually high chemical shift of the $\mathrm{H}-10$ signal is attributed to its proximity to the amide carbonyl. The other spectroscopic and analytical data were fully in accord with this structure. The bicyclic lactam 15 results from acid catalysed cyclisation of lactam 14 with elimination of aniline (Scheme 8).<smiles>O=C1CCCCC(C(=O)/C=C/Nc2ccccc2)N1</smiles>

14
Ph

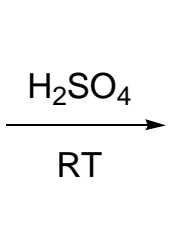

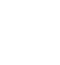

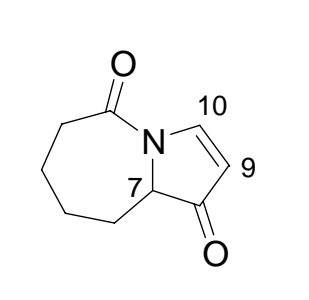

15

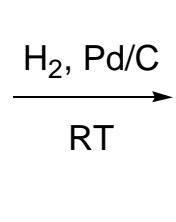

T 5

\section{Scheme 8}


In support of this proposal, treatment of compound $\mathbf{1 4}$ with concentrated sulfuric acid resulted in a quantitative conversion into the bicyclic compound $\mathbf{1 5}$. Thus, the series of products include two of the intermediates formed en route to the ultimate product $\mathbf{1 5}$ and they provide clear evidence for the mechanism of formation of 15. Hydrogenation of lactam 15 gave the known saturated bicyclic compound $\mathbf{1 6}^{20}$ in quantitative yield (Scheme 8).

No products arising from further reactions of the dihydropyrone $\mathbf{1 2}$ or the bicyclic compound 15 with hydrazoic acid were isolated. Moreover, treatment of both these compounds with hydrazoic acid resulted in the complete recovery of starting material. It is not surprising that the lactam did not react as its two carbonyl groups have diminished reactivity, being an amide and a vinylogous amide. However, the carbonyl of the dihydropyrone $\mathbf{1 2}$ is very similar to that of the enolised diketone 3a, so it might have been expected to react further. This could be interpreted as an indication that the Schmidt reaction of diketone $\mathbf{3}$ proceeds via a small amount of the diketo form, present at equilibrium with the dominant keto enol tautomer.

The formation of the 1-azabicyclic compound $\mathbf{1 5}$ was noteworthy since it contains an important substructure found in many alkaloids, including the Stemona alkaloids, ${ }^{21}$ such as croomine 17, and the lehmizidines, ${ }^{22}$ such as alkaloid 275A 18 (Figure 2). Synthetic derivatives of this ring system, ${ }^{23}$ such as the angiotensin-converting enzyme inhibitor $\mathbf{1 9}{ }^{24}$ have also attracted attention from medicinal chemists.

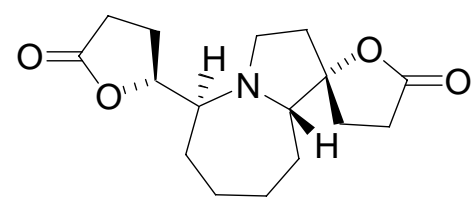

17

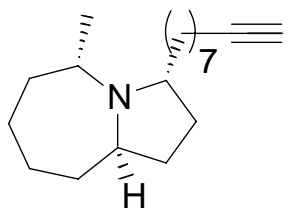

18

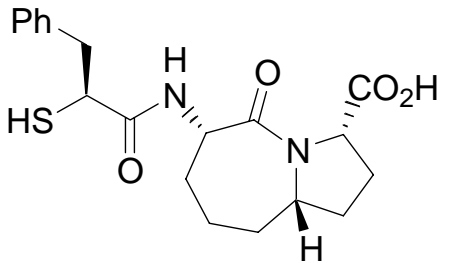

19

\section{Figure 2}

The formation of $\mathbf{1 5}$ was also of mechanistic interest, since it involved the unexpected addition of hydrazoic acid to a $\beta$-phenyl $\alpha, \beta$-unsaturated ketone. With these factors in mind, it was decided to optimize the reaction conditions for the formation of the 7-5 bicyclic compound 15 and also study the effect of the substituent in the $\beta$-position on the course of the reaction. Clearly, compound 15 arose from reaction of lactam 14 with a second molecule of hydrazoic acid. Therefore, cinnamoylcyclohexanone was treated with two equivalents of sodium azide using sulfuric acid as solvent. Using a reaction time of $8 \mathrm{~h}$, bicyclic lactam 15 was obtained in only 9\% yield, the major product being its precursor 14 (65\% yield). Using a longer reaction time $(24 \mathrm{~h})$ the desired product was obtained in a yield of $76 \%$. This yield was very gratifying considering the complexity of the reaction sequence involved. Changing the order of addition or increasing the quantity of sodium azide to four equivalents made no difference to the overall 
yield. Cinnamoylcyclohexanone was also reacted with a solution of hydrazoic acid in chloroform using various protic and Lewis acid catalysts. The mono-Schmidt product $\mathbf{1 3}$ was obtained in varying yields, but no traces of products resulting from a second addition of hydrazoic acid were observed.

In order to study the effect of the substituent in the $\beta$-position on the reactivity of the $\alpha, \beta$ unsaturated double bond, it was decided to study the reactions of compounds 3, 4, 5 and 7 with two equivalents of hydrazoic acid, under identical conditions to those used for cinnamoylcyclohexanone. The results are summarised in Scheme 9.

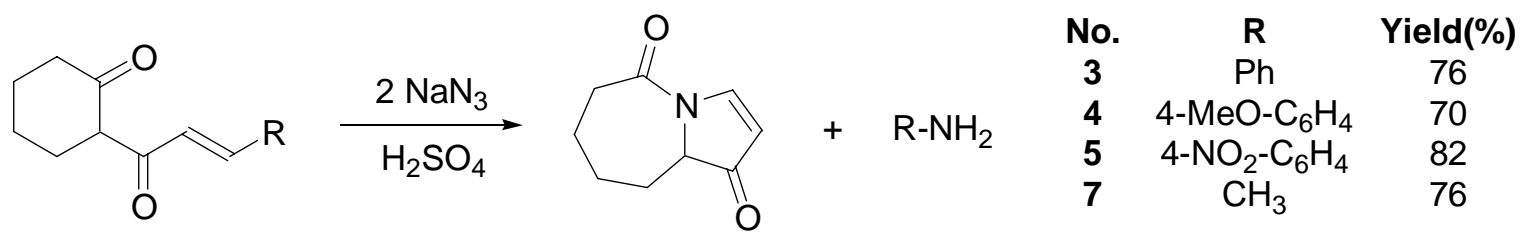

\section{Scheme 9}

It may be seen that even when the $\alpha, \beta$-double bond was in conjugation with the strongly electron releasing $p$-methoxyphenyl group, it was still sufficiently reactive for addition of hydrazoic acid, the resulting product being formed in $70 \%$ yield. The best yield was obtained using $p$-nitrocinnamoylcyclohexanone, the $\beta$-position being further activated by the presence of the strongly electron-withdrawing $p$-nitro group. It was thought the presence of a $\beta$-methyl group might change the nature of the products formed, alkyl groups having a lesser tendency to migrate than aryl groups. However, the bicyclic compound resulting from methyl group migration was formed in good yield, perhaps because the migration of the methyl is assisted by donation of electrons from the enolic $\mathrm{OH}$ group (see Scheme 7). In summary, the nature of the $\beta$-substituent has little effect on the reaction, and the bicyclic lactam 15 is probably best prepared from the unsubstituted cinnamoylcyclohexanone 3.

\section{The reaction of hydrazoic acid with other $\alpha, \beta$-unsaturated 1,3-diketones}

Reaction of the methylated diketone $\mathbf{1 0}$ with 2 equivalents of sodium azide, with concentrated sulfuric acid as the reaction medium, gave the desired bicyclic lactam $\mathbf{2 0}$ as the major product (75\%) (Scheme 10). Trace amounts of its precursors, lactams 21 and 22, were also isolated.

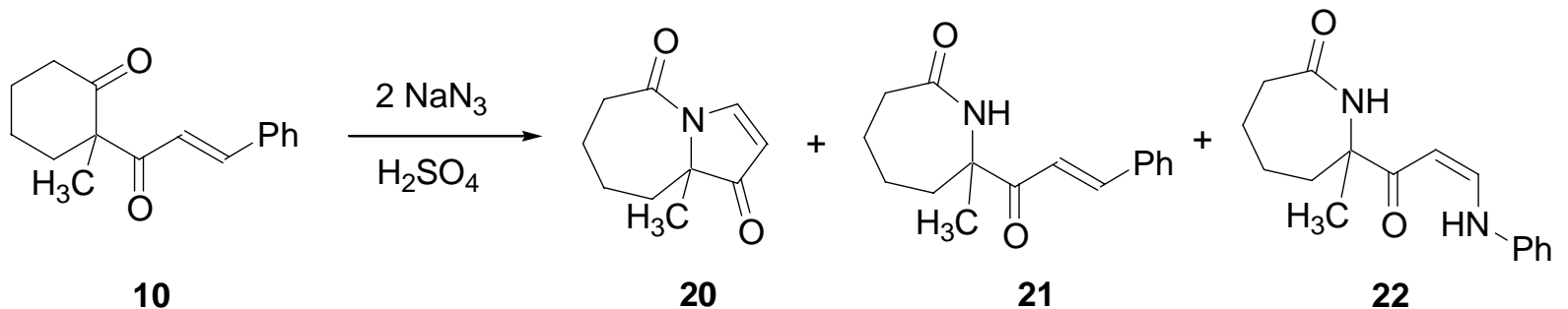




\section{Scheme 10}

Reaction of 2-cinnamoyl- $\alpha$-tetralone 9 with 1 equiv. of sodium azide using conc. sulfuric acid as catalyst gave the dihydropyrone 23 in 85\% yield (Scheme 11). It would appear that because this aryl ketone is less electrophilic, and more nucleophilic, the acid-catalysed cyclisation is faster than the addition of hydrazoic acid. The Schmidt reaction of compound 11, for which cyclisation is impossible, gave a complex mixture and no pure product could be isolated. It is evident that some variation in the structure of the cinnamoylcyclohexanone is tolerated, but dihydropyrone formation may intervene when the Schmidt reaction is disfavoured. Further exploration of the scope of this route to 7-5 systems has not yet been carried out.<smiles>O=C(/C=C/c1ccccc1)C1CCc2ccccc2C1=O</smiles>

9
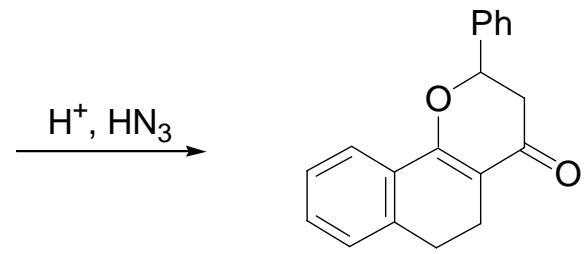

23

\section{Scheme 11}

It was also hoped to apply the Schmidt reaction of $\alpha, \beta$-unsaturated-1,3-diketones to the synthesis of some other 1-azabicyclic systems. Reaction of cinnamoylcyclopentanone $\mathbf{6}$ and cinnamoylcycloheptanone $\mathbf{8}$ with two equivalents of hydrazoic acid gave mixtures of products. The pyrones resulting from acid-catalysed cyclisation, 24 and 25, were isolated in low yields (8\% and 9\%, respectively) (Scheme 12), along with traces of cinnamic acid, possibly formed by hydrolytic cleavage of the 1,3-diketones. For cinnamoylcyclopentanone various experimental conditions were investigated but a complex mixture of products was obtained in every case.

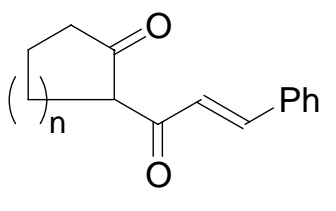

$6 n=1$

$8 \mathrm{n}=3$
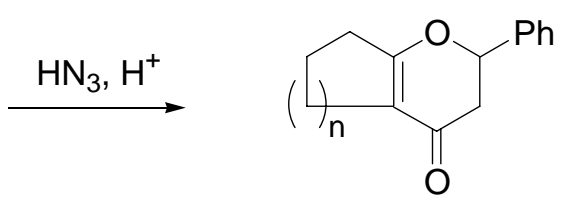

$24 n=1$

$25 n=3$

\section{Scheme 12}

The decreased reactivity of these cycloalkanones relative to the cyclohexanone 3 is in accord with relative rates of addition to the carbonyl group in 5-, 6-, and 7-membered cyclic ketones. Indeed, it has been reported that the rate of the Schmidt reaction and the yields of lactams are greater with 2-alkylcyclohexanones than with 2-alkylcylopentanones. ${ }^{18}$ The failure to isolate any Schmidt products may be a consequence of the further reduced reactivity of these ketones, 
relative to simple cyclopentanones and cycloheptanones, due to their highly conjugated keto enol structures, or to the very small amounts of diketo tautomers present (see above).

\section{Conclusions}

The reaction of hydrazoic acid with 2-(prop-2-enoyl)cyclohexanones provides a novel route to 1azabicyclic compounds in good yields, via a sequence involving two Schmidt type reactions. The nature of the substituent in the 3'- position, or the presence of a substituent in the 2-position, do not affect the course of the reaction. Attempted application to the synthesis of other 1-azabicyclic systems failed. Although this new route to bicyclic lactams process is much more limited in scope, at present, than the intramolecular Schmidt reactions of organic azides, ${ }^{3,4}$ it does possess some advantageous features. It uses readily accessible starting materials, it does not require the handling of organic azides, and it gives more heavily functionalised products, which will facilitate further synthetic manipulation. It is deserving of consideration as a simple and efficient method for the preparation of 7-5 bicyclic lactams.

\section{Experimental Section}

General Procedures. Melting points were determined on a Gallenkamp melting point block or a Büchi 530 capillary melting point apparatus and are uncorrected. ${ }^{1} \mathrm{H}$ NMR spectra were recorded at $270 \mathrm{MHz}$ on a JEOL JNM-GX $270 \mathrm{FT}$ spectrometer. ${ }^{13} \mathrm{C}$ NMR were recorded at $67.80 \mathrm{MHz}$ on the same instrument. Tetramethylsilane was used as internal reference in all cases. IR spectra were recorded on a Perkin Elmer 1710 FT spectrometer and a Galaxy series FTIR 3000 spectrometer from Mattson instruments. A VG Analytical 7070 mass spectrometer with attached INCOS 8700 data system in the E1 mode was used for recording mass spectra. Thin layer chromatography was performed on Merck precoated kieselgel 60F 254 slides. Merck silica 9385, particle size 0.04-0.063 (230-400) mesh was used for flash chromatographic separations. Tetrahydrofuran was distilled from sodium/benzophenone. Dichloromethane and diisopropylamine were distilled from calcium hydride. Combustion analyses were carried out by the Microanalytical Laboratory, University College Dublin.

\section{General procedure for the preparation of $\alpha, \beta$-unsaturated 1,3-diketones using sodium amide}

Cyclohexanone (11.30 g, $1.2 \times 10^{-1} \mathrm{~mol}$ ) was added dropwise to a stirred suspension of sodium amide (4.58 g, $\left.1.2 \times 10^{-1} \mathrm{~mol}\right)$ in dry ether $(100 \mathrm{~mL})$ and the mixture was stirred for $3 \mathrm{~h}$ under a constant stream of dry nitrogen. The mixture was then cooled to $-78{ }^{\circ} \mathrm{C}$ and the acid chloride $\left(4.0 \times 10^{-2} \mathrm{~mol}\right)$ in dry diethyl ether $(50 \mathrm{~mL})$ was added dropwise over $1 \mathrm{~h}$. The reaction mixture was stirred at $-78{ }^{\circ} \mathrm{C}$ for $1.5 \mathrm{~h}$ and then the temperature was allowed to increase slowly to $0{ }^{\circ} \mathrm{C}$. 
After $0.5 \mathrm{~h}$ at $0{ }^{\circ} \mathrm{C}$, the slurry was poured onto ice (100 g) and concentrated hydrochloric acid (25 mL). The ether layer was separated, washed with aqueous sodium bicarbonate and water, and then left stirring overnight with an aqueous $(20 \%, 100 \mathrm{~mL}$ ) solution of sodium metabisulfite (to remove the excess cyclohexanone). The organic layer was separated, washed with water and dried $\left(\mathrm{MgSO}_{4}\right)$. Removal of the solvent afforded a solid which was recrystallised from industrial methylated spirits (IMS).

(2Z,2'E)-2-(1-Hydroxy-3-phenylprop-2-enylidene)cyclohexanone (3). Prepared from cyclohexanone (11.30 g , $\left.1.2 \times 10^{-1} \mathrm{~mol}\right)$ and cinnamoyl chloride $\left(6.47 \mathrm{~g}, 4.0 \times 10^{-2} \mathrm{~mol}\right)$ according to the general procedure. Cinnamoyl cyclohexanone 3 was obtained as a yellow solid (6.64 g, 75\%), mp 92-93 ${ }^{\circ} \mathrm{C}$, (Lit. 92.5-93.5 $\left.{ }^{\circ} \mathrm{C}\right) .{ }^{11}{ }^{1} \mathrm{H}$ NMR (270 MHz, $\left.\mathrm{CDCl}_{3}\right): \delta 1.74-1.76$ (4H, m), 2.38-2.48 (2H, m), 2.52-2.60 (2H, m), 6.97 (1H, d, J = $15.8 \mathrm{~Hz}), 7.26-7.58$ (5H, m), $7.70(1 \mathrm{H}, \mathrm{d}, J=15.8 \mathrm{~Hz}), 16.83(1 \mathrm{H}, \mathrm{s}) .{ }^{13} \mathrm{C} \mathrm{NMR}\left(68 \mathrm{MHz}, \mathrm{CDCl}_{3}\right): \delta 21.75,23.00,23.87$, 34.20, 107.31, 119.66, 128.12, 128.87, 129.98, 135.35, 141.22, 180.39, 193.56.

(2Z,2' E)-2-[1-Hydroxy-3-(4-methoxyphenyl)prop-2-enylidene]cyclohexanone (4). Prepared from cyclohexanone $\left(11.30 \mathrm{~g}, 1.2 \times 10^{-1} \mathrm{~mol}\right)$ and $p$-methoxycinnamoyl chloride $(7.86 \mathrm{~g}, 4.0 \mathrm{x}$ $10^{-2} \mathrm{~mol}$ ) according to the general procedure. The $p$-methoxycinnamoyl cyclohexanone 4 was obtained as a yellow solid (5.98 g, 58\%), mp 113-115 ${ }^{\circ} \mathrm{C} .{ }^{1} \mathrm{H}$ NMR (270 MHz, $\left.\mathrm{CDCl}_{3}\right): \delta 1.74-$ 1.75 (4H, m), 2.38-2.47 (2H, m), 2.53-2.59 (2H, m), 3.84 (3H, s), 6.83 (1H, d, J = $15.8 \mathrm{~Hz})$, $6.90(2 \mathrm{H}, \mathrm{d}, J=8.8 \mathrm{~Hz}), 7.51(2 \mathrm{H}, \mathrm{d}, J=8.8 \mathrm{~Hz}), 7.67(1 \mathrm{H}, \mathrm{d}, J=15.8 \mathrm{~Hz}), 16.92(1 \mathrm{H}, \mathrm{s}) .{ }^{13} \mathrm{C}$ NMR (68 MHz, $\mathrm{CDCl}_{3}$ ): $\delta$ 21.80, 23.05, 23.87, 33.90, 55.39, 106.931, 114.35, 117.34, 128.12, 129.85, 141.19, 161.26, 181.64, 192.14. Anal. Calcd. for $\mathrm{C}_{16} \mathrm{H}_{18} \mathrm{O}_{3}$ : C, 74.40; H, 7.02. Found: C, 74.66; H, 6.86 .

(2Z,2' E)-2-[1-Hydroxy-3-(4-nitrophenyl)prop-2-enylidene]cyclohexanone (5). Prepared from cyclohexanone (11.30 g, 1.2 x 10-1 mol) and p-nitrocinnamoyl chloride (8.46 g, 4.0 x $\left.10^{-2} \mathrm{~mol}\right)$ according to the general procedure. The $p$-nitrocinnamoyl cyclohexanone $\mathbf{5}$ was obtained as a yellow solid (3.26 g, 30\%), mp 167-169 ${ }^{\circ} \mathrm{C} .{ }^{1} \mathrm{H}$ NMR (270 MHz, $\mathrm{CDCl}_{3}$ ): $\delta$ 1.72-2.06 (4H, m), 2.48-2.50 (2H, m), 2.54-2.68 (2H, m), 7.06 (1H, d, $J=15.8$ Hz), 7.40-7.88 (4H, m), 8.34 (1H, d, $J=15.8 \mathrm{~Hz}$ ), 16.50 (1H, s). Anal. Calcd. for $\mathrm{C}_{15} \mathrm{H}_{15} \mathrm{NO}_{4}$ : C, 65.93; H, 5.53; N, 5.13. Found: C, 65.91; H, 5.50; N, 4.84.

\section{General procedure for the preparation of $\alpha, \beta$-unsaturated 1,3-diketones using LDA}

A solution of the ketone ( 3 molar equiv.) in dry THF was added dropwise to LDA (3 molar equiv.), in dry THF (50 mL), at $-78^{\circ} \mathrm{C}$. The acid chloride (1 molar equiv.) in dry THF was then added dropwise over $1 \mathrm{~h}$ and the reaction mixture was stirred at $-78{ }^{\circ} \mathrm{C}$ for $1 \mathrm{~h}$. The temperature was then allowed to rise slowly to $0{ }^{\circ} \mathrm{C}$ and the mixture was stirred at this temperature for a further hour. The reaction was then worked up as described for the sodium amide procedure.

(2Z,2'E)-2-(1-Hydroxy-3-phenylprop-2-enylidene)cyclopentanone (6). Prepared from LDA (0.1189 mol), cyclopentanone (10.0 g, $0.1189 \mathrm{~mol})$ in dry THF (80 mL) and cinnamoyl chloride $\left(6.61 \mathrm{~g}, 4.0 \times 10^{-2} \mathrm{~mol}\right)$ in dry THF $(60 \mathrm{~mL})$, cinnamoylcyclopentanone 25 was obtained as a yellow solid (7.10 g, 83\%), mp 76-77 ${ }^{\circ} \mathrm{C} .{ }^{1} \mathrm{H}$ NMR (270 MHz, $\mathrm{CDCl}_{3}$ ): $\delta$ 1.80-1.95 (2H, m), 
2.36-2.42 (2H, m), 2.65-2.70 (2H, m), 6.51 (1H, dd, $J=2.4,15.7 \mathrm{~Hz}), 7.31-7.49$ (5H, m), 7.54 $(1 \mathrm{H}, \mathrm{d}, J=15.7 \mathrm{~Hz}), 12.92\left(1 \mathrm{H}\right.$, br s). ${ }^{13} \mathrm{C} \mathrm{NMR}\left(68 \mathrm{MHz}, \mathrm{CDCl}_{3}\right): \delta 20.52,25.48,37.99$, $111.14,119.76,127.76,128.86,129.68,135.46,138.97,163.81,210.54 . v_{\max }(\mathrm{KBr}): 1619$, $1652 \mathrm{~cm}^{-1} . \mathrm{m} / \mathrm{z}$ (EI): $214\left(\mathrm{M}^{+}, 47 \%\right), 196$ (34), 157 (51), 131 (100), 104 (72). Anal. Calcd. for $\mathrm{C}_{14} \mathrm{H}_{14} \mathrm{O}_{2}$ : C, 78.48; H, 6.59. Found: C, 78.39; H, 6.35.

(2Z,2'E)-2-(1-Hydroxy-3-phenylprop-2-enylidene)cyclohexanone (3). Prepared from LDA $\left(1.02 \times 10^{-1} \mathrm{~mol}\right)$, cyclohexanone $\left(10.0 \mathrm{~g}, 1.02 \times 10^{-1} \mathrm{~mol}\right)$ in dry THF (80 mL) and cinnamoyl chloride (5.66 g, $\left.3.4 \times 10^{-2} \mathrm{~mol}\right)$ in dry THF (60 mL), cinnamoyl cyclohexanone 3 was obtained as a yellow solid (6.67 g, 86\%). The spectroscopic data matched those previously reported.

(2Z,2'E)-2-(1-Hydroxybut-2-enylidene)cyclohexanone (7). Prepared from LDA (1.02 x $\left.10^{-1} \mathrm{~mol}\right)$, cyclohexanone (10.0 g, $\left.1.02 \times 10^{-1} \mathrm{~mol}\right)$ in dry THF $(80 \mathrm{~mL})$ and 2-butenoyl chloride (3.52 g, $3.4 \mathrm{x}$

$10^{-2} \mathrm{~mol}$ ) in dry THF (50 mL), the diketone 7 was obtained as a pale yellow solid (4.57 $\left.\mathrm{g}, 81 \%\right) \mathrm{mp} 46-$ $48^{\circ} \mathrm{C}$ (Lit., $\left.46-48{ }^{\circ} \mathrm{C}\right) .{ }^{1} \mathrm{H}$ NMR $\left(270 \mathrm{MHz}, \mathrm{CDCl}_{3}\right): \delta$ 1.67-1.78 (4H, m), 1.94 (3H, dd, $\left.J=1.3,6.7 \mathrm{~Hz}\right)$, 2.34-2.47 (4H, m), 6.34 (1H, dd, $J=1.3,14.7 \mathrm{~Hz}), 6.98$ (1H, dq, $J=6.7,14.7 \mathrm{~Hz}), 16.72$ (1H, br s). ${ }^{13} \mathrm{C}$ NMR (68 MHz, $\mathrm{CDCl}_{3}$ ): $\delta 18.47$ (CH3), 21.73, 22.99, 23.71, 33.66, 106.06, 124.47, 141.60, 182.14, 191.76. $v_{\max }\left(\mathrm{CHCl}_{3}\right): 1602,1651 \mathrm{~cm}^{-1} . \mathrm{m} / \mathrm{z}$ (EI): 166 (M+, 9\%), 151 (63), 138 (5), 123 (15), 95 (52), 69 (100). Anal. Calcd. for $\mathrm{C}_{10} \mathrm{H}_{14} \mathrm{O}_{2}$ : C, 72.26; H, 8.49. Found: C, 71.99; H, 8.38.

(2Z,2'E)-2-(1-Hydroxy-3-phenylprop-2-enylidene)cycloheptanone (8). Prepared from LDA (5.35 x $\left.10^{-2} \mathrm{~mol}\right)$, cycloheptanone $\left(6.0 \mathrm{~g}, 5.35 \times 10^{-2} \mathrm{~mol}\right)$ in dry THF (50 mL) and cinnamoyl chloride (2.97 g, $\left.1.78 \times 10^{-2} \mathrm{~mol}\right)$ in dry THF (40 mL). Cinnamoyl cycloheptanone 8 was obtained as a yellow solid (3.5 g, 83\%), mp 94-95 ${ }^{\circ} \mathrm{C} .{ }^{1} \mathrm{H}$ NMR (270 MHz, $\left.\mathrm{CDCl}_{3}\right): \delta 1.61-1.80$ (6H, m), 2.53-2.66 (4H, m), 6.95 (1H, dd, $J=1.1,16.5 \mathrm{~Hz}), 7.29-7.58$ (5H, m), 7.65 (1H, d, $J$ $=16.5 \mathrm{~Hz}), 16.10(1 \mathrm{H}, \mathrm{d}, J=1.1 \mathrm{~Hz}) .{ }^{13} \mathrm{C} \mathrm{NMR}\left(68 \mathrm{MHz}, \mathrm{CDCl}_{3}\right): \delta 24.96,26.26,29.53,31.40$, 42.50, 112.72, 119.16, 129.50, 128.82, 127.77, 135.75, 139.42, 170.53, 207.47. $v_{\max }(\mathrm{KBr})$ : 1583, $1632 \mathrm{~cm}^{-1} . \mathrm{m} / \mathrm{z}$ (EI): $242\left(\mathrm{M}^{+}, 14 \%\right), 224$ (12), 165 (22), 131 (100), 103 (57). Anal. Calcd. for $\mathrm{C}_{16} \mathrm{H}_{18} \mathrm{O}_{2}$ : C, 79.31; $\mathrm{H}, 7.49$. Found: C, 79.26; $\mathrm{H}, 7.51$.

2-Cinnamoyl $\alpha$-tetralone (9). Prepared from LDA (4.1 x 10 $\left.0^{-2} \mathrm{~mol}\right)$, $\alpha$-tetralone $\left(6.0 \mathrm{~g}, 4.1 \times 10^{-2}\right.$ $\mathrm{mol}$ ) in the dry THF (60 mL) and cinnamoyl chloride (2.28 g, $1.37 \times 10^{-2} \mathrm{~mol}$ ) in dry THF (30 $\mathrm{mL}$ ). 2-Cinnamoyl $\alpha$-tetralone 9 was obtained as a yellow solid (3.25 g, 88\%), mp 104-106 ${ }^{\circ} \mathrm{C}$. ${ }^{1} \mathrm{H}$ NMR (270 MHz, $\left.\mathrm{CDCl}_{3}\right): \delta 2.79-2.98(4 \mathrm{H}, \mathrm{m}), 7.05(1 \mathrm{H}, \mathrm{d}, J=15.7 \mathrm{~Hz}), 7.19-7.60(8 \mathrm{H}, \mathrm{m})$, $7.72(1 \mathrm{H}, \mathrm{d}, J=15.7 \mathrm{~Hz}), 8.01(1 \mathrm{H}, \mathrm{dd}, J=1.5,7.7 \mathrm{~Hz}), 16.76(1 \mathrm{H}, \mathrm{s}, \mathrm{br}) .{ }^{13} \mathrm{C}$ NMR $(68 \mathrm{MHz}$, $\left.\mathrm{CDCl}_{3}\right): \delta 22.57,28.29,107.12,119.01,126.53,126.87,127.62,127.93,128.82,129.78,132.52$, 132.65, 135.43, 140.24, 141.82, 174.96. $v_{\max }(\mathrm{KBr}): 1626,1640 \mathrm{~cm}^{-1} \cdot \mathrm{m} / \mathrm{z}(\mathrm{EI}): 276\left(\mathrm{M}^{+}, 72 \%\right)$, 258 (53), 199 (54), 144(48), 131 (100), 115 (85). Anal. Calcd. for $\mathrm{C}_{19} \mathrm{H}_{16} \mathrm{O}_{2}$ : C, 82.58; H, 5.84. Found: C, 82.49; H, 5.86.

\section{General procedure for the $\alpha$-methylation of $\alpha, \beta$-unsaturated 1,3-diketones}

Tetrabutylammonium fluoride (3 molar equiv 1.6 M solution in THF) was added to the diketone at $0{ }^{\circ} \mathrm{C}$ and the solvent was removed under reduced pressure. The resulting orange solid was dissolved in dry dichloromethane $(25 \mathrm{~mL})$, iodomethane (4 molar equiv.) was added, and the 
mixture was stirred at $40{ }^{\circ} \mathrm{C}$ for $1 \mathrm{~h}$. The solvent was removed, diethyl ether added and the precipitated tetrabutylammonium iodide was filtered off. The filtrate was concentrated affording a white solid which was recrystallised from IMS.

(E)-2-Methyl-2-(3-phenylprop-2-enoyl)cyclohexanone (10). Prepared from tetrabutylammonium fluoride (9.0 mL, $1.6 \mathrm{~mol}$ solution in THF), 2-cinnamoyl cyclohexanone (1.0 g, $4.4 \mathrm{x}$ $10^{-3} \mathrm{~mol}$ ) and iodomethane (2.5 g, $\left.1.76 \mathrm{x} 10^{-2} \mathrm{~mol}\right)$. 2-Methyl-2-cinnamoylcyclo-hexanone 10 was obtained as a white solid (0.92 g, 87\%), mp 65-66 ${ }^{\circ} \mathrm{C} .{ }^{1} \mathrm{H}$ NMR (270 MHz, $\left.\mathrm{CDCl}_{3}\right): \delta 1.31$ (3H, s), 1.47-2.65 (8H, m), 6.80 (1H, d, $J=15.6 \mathrm{~Hz}), 7.35-7.40$ (3H, m), 7.52-7.56 (2H, m), $7.73(1 \mathrm{H}, \mathrm{d}, J=15.6 \mathrm{~Hz}) .{ }^{13} \mathrm{C} \mathrm{NMR}\left(68 \mathrm{MHz}, \mathrm{CDCl}_{3}\right): \delta 21.07,22.43,27.76,36.90,42.03$, 63.15, 120.47, 128.63, 128.95, 130.85, 134.25, 144.72, 197.14, 211.04. $v_{\max }\left(\mathrm{CHCl}_{3}\right): 1608$, 1678, $1715 \mathrm{~cm}^{-1}$. Anal. Calcd. for $\mathrm{C}_{16} \mathrm{H}_{18} \mathrm{O}_{2}$ : C, 79.31; H, 7.49. Found: C, 79.15; H, 7.49.

(E)-2-Methyl-2-cinnamoyl- $\alpha$-tetralone (11). Prepared from tetrabutylammonium fluoride (8ml, 1.6 M solution in THF), 2-cinnamoyl- $\alpha$-tetralone (1.0 g, $\left.3.6 \times 10^{-3} \mathrm{~mol}\right)$ and iodomethane ( $2.1 \mathrm{~g}$, $\left.1.4 \times 10^{-2} \mathrm{~mol}\right)$. 2-Methyl-2-cinnamoyl- $\alpha$-tetralone 11 was obtained as a white solid $(0.84 \mathrm{~g}$, 80\%), mp 73-75 ${ }^{\circ} \mathrm{C} .{ }^{1} \mathrm{H}$ NMR (270 MHz, $\left.\mathrm{CDCl}_{3}\right): \delta 1.41(3 \mathrm{H}, \mathrm{s}), 1.75-3.20(4 \mathrm{H}, \mathrm{m}), 6.90(1 \mathrm{H}$, d, $J=15.5 \mathrm{~Hz}), 7.15-7.52(8 \mathrm{H}, \mathrm{m}), 7.65(1 \mathrm{H}, \mathrm{d}, J=15.5 \mathrm{~Hz}), 8.00(1 \mathrm{H}, \mathrm{dd}, J=1.5,7.5 \mathrm{~Hz}) .{ }^{13} \mathrm{C}$ NMR (68 MHz, $\mathrm{CDCl}_{3}$ ): $\delta$ 21.28, 25.96, 32.57, 59.16, 120.94, 126.70, 127.86, 128.63, 128.84, 128.92, 130.66, 133.77, 132.11, 134.39, 143.85, 144.15, 196.81, 198.59. $v_{\max }(\mathrm{KBr}): 1615,1680$, $1705 \mathrm{~cm}^{-1} . \mathrm{m} / \mathrm{z}$ (EI): $290\left(\mathrm{M}^{+}, 6 \%\right), 272$ (6), 131 (100), 121 (25), 103 (21). Anal. Calcd. for $\mathrm{C}_{20} \mathrm{H}_{18} \mathrm{O}_{2}$ : C, 82.73; H, 6.25. Found: C, 82.58; H, 6.19.

\section{The reaction of cinnamoyl cyclohexanone with one equivalent of hydrazoic acid}

Sodium azide $\left(0.29 \mathrm{~g}, 4.39 \times 10^{-3} \mathrm{~mol}\right)$ was added in portions to a solution of cinnamoyl cyclohexanone in concentrated sulfuric acid $(10 \mathrm{~mL})$ at $0{ }^{\circ} \mathrm{C}$ and the mixture was stirred for $8 \mathrm{~h}$. The mixture was poured onto ice (100 g) and extracted with chloroform (4 x $100 \mathrm{~mL})$. The aqueous layer was neutralised with aqueous sodium hydroxide (20\%) and further extracted with chloroform ( 2 x $100 \mathrm{~mL}$ ). The combined chloroform extracts were washed with water, dried $\left(\mathrm{MgSO}_{4}\right)$ and evaporated to dryness. The resulting yellow oil was fractionated by preparative thin layer chromatography (PLC) using chloroform-methanol (95:5) as eluant. Four compounds were isolated, in order of elution as follows:

2-Phenyl-2,3,5,6,7,8-hexahydro-4H-1-benzopyran-4-one (12). mp $43-45^{\circ} \mathrm{C}$ (Lit. $\left.56-57{ }^{\circ} \mathrm{C}\right) .{ }^{25}$ ${ }^{1} \mathrm{H}$ NMR (270 MHz, $\left.\mathrm{CDCl}_{3}\right): \delta$ 1.51-1.85 (4H, m), 2.20-2.43 (4H, m), $2.63(1 \mathrm{H}, \mathrm{dd}, J=3.5$, $16.8 \mathrm{~Hz}), 2.88(1 \mathrm{H}, \mathrm{dd}, J=14.5,16.8 \mathrm{~Hz}), 5.34(1 \mathrm{H}, \mathrm{dd}, J=3.5,14.5 \mathrm{~Hz}), 7.40$ (5H, s). Anal. Calcd. for $\mathrm{C}_{15} \mathrm{H}_{16} \mathrm{O}_{2}$ : C, 78.92; $\mathrm{H}, 7.06$. Found: C, 78.65; H, 7.00.

(E)-7-(3-Phenylprop-2-enoyl)hexahydro-2-azepinone 13, mp 107-108 ${ }^{\circ} \mathrm{C} .{ }^{1} \mathrm{H}$ NMR (270 MHz, $\left.\mathrm{CDCl}_{3}\right): \delta 1.30-2.54(8 \mathrm{H}, \mathrm{m}), 4.36(1 \mathrm{H}, \mathrm{dd}, J=4.0,9.1 \mathrm{~Hz}), 6.82(1 \mathrm{H}, \mathrm{d}, J=15.9 \mathrm{~Hz}), 6.90(1 \mathrm{H}$, s, br), 7.30-7.61 (5H, m), $7.75(1 \mathrm{H}, \mathrm{d}, J=15.9 \mathrm{~Hz}) .{ }^{13} \mathrm{C} \mathrm{NMR}\left(68 \mathrm{MHz}, \mathrm{CDCl}_{3}\right): \delta 22.94,30.19$, 33.20, 37.13, 61.26, 121.10, 128.65, 129.11, 131.29, 133.79, 145.41, 175.54, 194.62. $v_{\max }(\mathrm{KBr})$ : 1613, 1655, $1695 \mathrm{~cm}^{-1} . \mathrm{m} / \mathrm{z}$ (EI): 243 (M+3\%), 146 (12), 131 (22), 112 (100), 103 (23). Anal. Calcd. for $\mathrm{C}_{15} \mathrm{H}_{17} \mathrm{NO}_{2}$ : C, 74.05; H, 7.04; N, 5.76. Found: C, 73.82; H, 6.91, N, 5.92. 
(Z)-7-[3-(Phenylamino)prop-2-enoyl]hexahydro-2-azepinone (14). mp 171-173 ${ }^{\circ} \mathrm{C} .{ }^{1} \mathrm{H}$ NMR (270 MHz, $\left.\mathrm{CDCl}_{3}\right): \delta 1.40-2.55(8 \mathrm{H}, \mathrm{m}), 4.10$ (1H, dd, $\left.J=4.5,9.1 \mathrm{~Hz}\right), 5.27(1 \mathrm{H}, \mathrm{d}, J=8.2 \mathrm{~Hz})$, 6.90 (1H, s, br), 7.01-7.35 (5H, m), 7.40 (1H, dd, $J=8.2,12.9 \mathrm{~Hz}), 11.30(1 \mathrm{H}, \mathrm{d}, J=12.9 \mathrm{~Hz})$. ${ }^{13} \mathrm{C}$ NMR (68 MHz, $\left.\mathrm{CDCl}_{3}\right): \delta 23.03,30.17,34.91,37.17,60.36,93.44,116.37,124.15,129.63$, 139.72, 145.51, 176.23, 195.05. $v_{\max }(\mathrm{KBr}): 1582,1606,1649 \mathrm{~cm}^{-1} . \mathrm{m} / \mathrm{z}(\mathrm{EI}): 258\left(\mathrm{M}^{+}, 7 \%\right), 146$ (100), 112 (6). Anal. Calcd. for $\mathrm{C}_{15} \mathrm{H}_{18} \mathrm{~N}_{2} \mathrm{O}_{2}$ : C, 69.74; H, 7.02; N, 10.84. Found: C, 69.68; H, 7.02; N, 10.78.

1-Azabicyclo[5.3.0]dec-9-ene-2,8-dione (15). mp 75-76 ${ }^{\circ} \mathrm{C} .{ }^{1} \mathrm{H}$ NMR (270 $\left.\mathrm{MHz}, \mathrm{CDCl}_{3}\right): \delta$ 1.23-2.81 (8H, m), 3.92 (1H, dd, $J=1.7,11.7 \mathrm{~Hz}), 5.72(1 \mathrm{H}, \mathrm{d}, J=4.2 \mathrm{~Hz}), 8.71$ (1H, d, $J=4.2$ $\mathrm{Hz}) .{ }^{13} \mathrm{C} \mathrm{NMR}\left(68 \mathrm{MHz}_{\mathrm{CDCl}}\right.$ ): $\delta 24.15,29.26,32.36,37.62,64.92,109.38,155.51,169.92$, 201.49. $v_{\max }(\mathrm{KBr}): 1675-1690 \mathrm{~cm}^{-1} . \mathrm{m} / \mathrm{z}(\mathrm{EI}): 165\left(\mathrm{M}^{+}, 95 \%\right), 147$ (5), 137 (12), 122 (10), 109 (100), 96 (88), 80 (71), 70 (81). Anal. Calcd. for $\mathrm{C}_{9} \mathrm{H}_{11} \mathrm{NO}_{2}$ : C, 65.44; H, 6.71; N, 8.48. Found: C, 65.27; H, 6.81; N, 8.52.

\section{1-Azabicyclo[5.3.0]dec-9-ene-2,8-dione (15)}

The reaction was repeated as previously, but using sodium azide $\left(0.58 \mathrm{~g}, 8.7 \mathrm{x} 10^{-3} \mathrm{~mol}, 2\right.$ equiv.). The crude product was purified by PLC using chloroform-methanol (95:5) as eluant, affording compounds $\mathbf{1 4}$ and $\mathbf{1 5}$ in yields of 65\% and 9\% respectively. The reaction was also repeated as previously but using sodium azide ( $0.58 \mathrm{~g}, 8.7 \times 10^{-3} \mathrm{~mol}, 2$ equiv.), concentrated sulfuric acid (25ml) and a reaction time of $24 \mathrm{~h}$. After work up, the crude product was purified by flash column chromatography using chloroform as eluant affording the bicyclic compound 15 in $76 \%$ yield.

\section{Acid-catalysed cyclisation of enaminone (14)}

A solution of lactam $14\left(0.40 \mathrm{~g}, 1.5 \times 10^{-3} \mathrm{~mol}\right)$ in concentrated sulfuric acid (20 mL) was stirred at room temperature for $24 \mathrm{~h}$. The reaction was worked up as in the previous experiment, and the product was purified by flash column chromatography using chloroform as eluant to give the bicyclic compound 15 (0.26 g, 96\%).

\section{Hydrogenation of 1-azabicyclo[5.3.0]dec-9-ene-2,8-dione}

Hydrogen gas was bubbled through a stirred mixture of Pd/C (0.04 g), unsaturated lactam 15 $\left(0.40 \mathrm{~g}, 2.4 \times 10^{-3} \mathrm{~mol}\right)$ and ethanol $(40 \mathrm{~mL})$ for $4 \mathrm{~h}$. The mixture was filtered and the $\mathrm{Pd} / \mathrm{C}$ washed with ethanol ( $2 \times 10 \mathrm{~mL})$. Removal of the solvent gave a colourless oil which was purified by flash column chromatography using chloroform as eluant to give 1azabicyclo[5.3.0]dec-2,8-dione 16 (0.40 g, 100\%). ${ }^{1} \mathrm{H}$ NMR (270 MHz, $\left.\mathrm{CDCl}_{3}\right): \delta$ 1.10-2.82 (10H, m), 3.58-4.06 (3H, m). ${ }^{13} \mathrm{C}$ NMR (68 MHz, $\left.\mathrm{CDCl}_{3}\right): \delta 22.99,29.45,31.73,34.75,37.87$, 40.65, 63.53, 174.66, 212.08. $v_{\max }(\mathrm{KBr}): 1640,1760 \mathrm{~cm}^{-1} . \mathrm{m} / \mathrm{z}(\mathrm{EI}): 167\left(\mathrm{M}^{+}, 51 \%\right), 149$ (6), 139 (100), 124 (31), 111 44), 83 (67). Anal. Calcd. for $\mathrm{C}_{9} \mathrm{H}_{13} \mathrm{NO}_{2}$ : C, 64.65; H, 7.84; N, 8.38. Found: C, 64.51; H, 7.59; N, 8.26. 


\section{Reaction 2-methylcinnamoylcyclohexanone 10 with 2 equivalents of hydrazoic acid}

Sodium azide $\left(0.54 \mathrm{~g}, 8.31 \times 10^{-3} \mathrm{~mol}\right)$ was added in portions to a solution of the diketone $\mathbf{1 0}$ $\left(1.0 \mathrm{~g}, 4.13 \times 10^{-3} \mathrm{~mol}\right)$ in concentrated sulfuric acid $(20 \mathrm{~mL})$. After $24 \mathrm{~h}$, the reaction was worked up as described above. The crude product was purified by flash column chromatography using chloroform as eluant to give 3 products:

1-Aza-7-methyl-bicyclo[5.3.0]dec-9-ene-2,8-dione (20). a white solid (0.55 g, 75\%), mp 53$55{ }^{\circ} \mathrm{C} .{ }^{1} \mathrm{H}$ NMR (270 MHz, $\left.\mathrm{CDCl}_{3}\right): \delta 1.20-1.61(2 \mathrm{H}, \mathrm{m}), 1.44(3 \mathrm{H}, \mathrm{s}), 1.80-2.11(4 \mathrm{H}, \mathrm{m})$, 2.60-2.75 (2H, m), $5.72(1 \mathrm{H}, \mathrm{d}, J=4.4 \mathrm{~Hz}), 8.78(1 \mathrm{H}, \mathrm{d}, J=4.4 \mathrm{~Hz}) .{ }^{13} \mathrm{C} \mathrm{NMR}(68 \mathrm{MHz}$, $\left.\mathrm{CDCl}_{3}\right): \delta 19.35,23.74,24.54,34.56,37.36,67.15,106.96,155.06,170.07,204.98 . v_{\max }(\mathrm{KBr})$ : 1670-1690 $\mathrm{cm}^{-1} . \mathrm{m} / \mathrm{z}(\mathrm{EI}): 179\left(\mathrm{M}^{+}, 93 \%\right), 164$ (7), 161 (6), 123 (100). Anal. Calcd. for $\mathrm{C}_{10} \mathrm{H}_{13} \mathrm{NO}_{2}$ : C, 67.02; H, 7.31; N, 7.82. Found: C, 66.89; H, 7.21; N, 7.89.

(Z)-3-Methyl-3-[3-(phenylamino)prop-2-enoyl]cyclohexanone (22). a white solid (35 mg, 3\%), mp 181-183 ${ }^{\circ} \mathrm{C} .{ }^{1} \mathrm{H}$ NMR (270 MHz, $\mathrm{CDCl}_{3}$ ): $\delta 1.45$ (3H, s), 1.51-1.80 (4H, m), 2.35-2.50 $(4 \mathrm{H}, \mathrm{m}), 5.66(1 \mathrm{H}, \mathrm{d}, J=8.0 \mathrm{~Hz}), 6.83(1 \mathrm{H}, \mathrm{s}, \mathrm{br}), 7.04-7.36$ (5H, m), 7.43 (1H, dd, $J=8.0,12.6$ $\mathrm{Hz}), 11.90(1 \mathrm{H}, \mathrm{d}, J=12.6 \mathrm{~Hz}) .{ }^{13} \mathrm{C} \mathrm{NMR}\left(68 \mathrm{MHz}, \mathrm{CDCl}_{3}\right): \delta 29.44(\mathrm{CH}), 22.88,25.78$, 37.36, 38.31, 62.54, 91.93, 115.94, 123.93, 129.62, 139.83, 149.48, 178.10, 201.33. $v_{\max }(\mathrm{KBr})$ : 1606, $1650 \mathrm{~cm}^{-1} . \mathrm{m} / \mathrm{z}$ (EI): $272\left(\mathrm{M}^{+}, 10 \%\right), 257$ (4), 146 (25), 126 (100). Anal. Calcd. for $\mathrm{C}_{16} \mathrm{H}_{20} \mathrm{~N}_{2} \mathrm{O}_{2}$ : C, 70.56; H, 7.40; N, 10.29. Found: C, 70.81; H, 7.31; N, 10.11.

(E)-3-Methyl-3-(3-phenylprop-2-enoyl)- $\varepsilon$-caprolactam (21). a white solid, mp $85-87{ }^{\circ} \mathrm{C} .{ }^{1} \mathrm{H}$ NMR (270 MHz, $\left.\mathrm{CDCl}_{3}\right): \delta 1.46(3 \mathrm{H}, \mathrm{s}), 1.48-2.50(8 \mathrm{H}, \mathrm{m}), 6.91(1 \mathrm{H}, \mathrm{d}, J=15.8 \mathrm{~Hz}), 6.95(1 \mathrm{H}$, s, br), 7.09-7.60 (5H, m), $7.61(1 \mathrm{H}, \mathrm{d}, J=15.8 \mathrm{~Hz}) .{ }^{13} \mathrm{C} \mathrm{NMR}\left(68 \mathrm{MHz}, \mathrm{CDCl}_{3}\right): \delta 24.26,21.83$, 25.87, 35.32, 38.14, 64.12, 119.87, 128.74, 129.22, 131.41, 133.71, 149.37, 177.08, 198.98. $v_{\max }$ (KBr): 1611, 1650, $1690 \mathrm{~cm}^{-1} . \mathrm{m} / \mathrm{z}$ (EI): $257\left(\mathrm{M}^{+}, 8\right), 131$ (31), 126 (100). Anal. Calcd. for $\mathrm{C}_{16} \mathrm{H}_{19} \mathrm{NO}_{2}$ : C, 74.68; H, 7.44; N, 5.44. Found: C, 74.83; H, 7.47; N, 5.39.

Attempted Schmidt reaction of 2-cinnamoyl- $\alpha$-tetralone (9). The Schmidt reaction was carried out on 2-cinnamoyl- $\alpha$-tetralone 9 using one equivalent of sodium azide as described previously for cinnamoyl cyclohexanone. The crude product was purified by flash column chromatography using diethyl ether-light petroleum $\left(40-60{ }^{\circ} \mathrm{C}\right)(20: 80)$ as eluant to give 2phenyl-5,6-dihydro-naphtho[1,2b]pyran-4-one 23 (85\% yield), as a white solid, mp $71-73{ }^{\circ} \mathrm{C} .{ }^{1} \mathrm{H}$ NMR (270 MHz, CDCl $): \delta 2.50-2.95(5 \mathrm{H}, \mathrm{m}), 2.99$ (1H, dd, $J=12.2,16.5 \mathrm{~Hz}), 5.42$ (1H, dd, $J$ = 4.6, $12.2 \mathrm{~Hz}), 7.10-7.92(9 \mathrm{H}, \mathrm{m}) .{ }^{13} \mathrm{C} \mathrm{NMR}\left(68 \mathrm{MHz}, \mathrm{CDCl}_{3}\right): \delta 18.62,27.46,42.97,80.04$, 110.82, 124.33, 126.05, 126.57, 127.81, 128.62, 128.76, 131.05, 129.15, 138.72, 140.04, 164.02, 191.39. $v_{\max }(\mathrm{KBr}): 1660 \mathrm{~cm}^{-1} \cdot \mathrm{m} / \mathrm{z}(\mathrm{EI}): 276\left(\mathrm{M}^{+}, 11 \%\right), 258$ (8), 104 (100).

Attempted Schmidt reaction of cinnamoylcyclopentanone (6). The Schmidt reaction was carried out on cinnamoyl cyclopentanone using one and two equivalents of sodium azide, as described previously for cinnamoyl cyclohexanone. The crude product from each reaction was shown to contain numerous products on analysis by TLC. PLC using chloroform as eluant gave 2,3-dihydro-2-phenylcyclopenta[6]pyran-4-one 24 (8\%), as a white solid, mp 41-43 ${ }^{\circ} \mathrm{C}$. ${ }^{1} \mathrm{H}$ NMR (270 MHz, $\left.\mathrm{CDCl}_{3}\right): \delta$ 1.95-2.01 (2H, m), 2.58-2.67 (5H, m), 2.83 (1H, dd, $J=16.9,13.9$ 
Hz), 5.49 (1H, dd, $J=3.6,13.9 \mathrm{~Hz}), 7.41(5 \mathrm{H}, \mathrm{s}) \cdot v_{\max }(\mathrm{KBr}): 1656 \mathrm{~cm}^{-1} \cdot \mathrm{m} / \mathrm{z}(\mathrm{EI}): 214\left(\mathrm{M}^{+}, 5 \%\right)$, 196 (7), 104 (100), 78 (17). Anal. Calcd. for $\mathrm{C}_{14} \mathrm{H}_{14} \mathrm{O}_{2}$ : C, 78.48; H, 6.59. Found: C, 78.39; H, 6.42 .

Attempted Schmidt reaction of cinnamoyl cycloheptanone (8). The Schmidt reaction was carried out on cinnamoyl cycloheptanone using one and two equivalents of sodium azide, as described previously for cinnamoyl cyclohexanone. The crude product from each reaction was shown to contain numerous components on analysis by TLC. PLC using diethyl ether-light petroleum $\left(40-60{ }^{\circ} \mathrm{C}\right.$ ) as eluant (50:50) gave 2-phenyl-2,3-dihydrocyclohepta[b]pyran-4-one 25 (9\%), as a white solid, mp 59-61 ${ }^{\circ} \mathrm{C}$ (Lit. 92.5-93.5 ${ }^{\circ} \mathrm{C}$ ). ${ }^{25}{ }^{1} \mathrm{H}$ NMR $\left(270 \mathrm{MHz}, \mathrm{CDCl}_{3}\right): \delta 1.40-$ $2.71(11 \mathrm{H}, \mathrm{m}), 2.81(1 \mathrm{H}, \mathrm{dd}, J=14.4,16.9 \mathrm{~Hz}), 5.35(1 \mathrm{H}, \mathrm{dd}, J=3.6,14.4 \mathrm{~Hz}), 7.35(5 \mathrm{H}, \mathrm{s}) .{ }^{13} \mathrm{C}$ NMR (68 MHz, $\left.\mathrm{CDCl}_{3}\right): \delta 22.00,24.91,26.95,31.76,34.99,42.33,80.09,116.78,126.13$, 128.65, 128.74, 138.59, 177.17, 191.04. $v_{\max }(\mathrm{KBr}): 1659 \mathrm{~cm}^{-1} \cdot \mathrm{m} / \mathrm{z}$ (EI): $242\left(\mathrm{M}^{+}, 15 \%\right), 224$ (6), 104 (100). Anal. Calcd. for $\mathrm{C}_{16} \mathrm{H}_{18} \mathrm{O}_{2}$ requires: C, 79.31; H, 7.49. Found: C, 78.99; H, 7.32.

\section{Acknowledgements}

We thank Dr. Anne Sheehy for the characterisation of compounds 3, 4, and 5, and Dr G. Gilligan for assistance with the acylation reactions. We are indebted to University College Dublin for financial support.

It is a pleasure to dedicate this paper to Professor Tony McKervey. His contributions to organic chemistry have been enormous, and he has inspired many students (MC included) to pursue careers in synthetic chemistry. We wish him well in the transition to what is sure to be an equally fruitful new phase in his life.

\section{References}

1. (a) Wolff, H. Org. React. 1946, 3, 307. (b) Abramovich, R. A.; Kyba, E. P. In The Chemistry of the Azido Group; Patai, S., Ed.; John Wiley \& Sons: London, 1971; pp 221-329. (c) Krow, G. R. Tetrahedron 1981, 37, 1283.

2. (a) Gracias, V.; Milligan, G. L.; Aube, J. J. Am. Chem. Soc. 1995, 117, 8047. (b) Pearson, W. H.; Fang, W.-k. J. Org. Chem. 1995, 60, 4960. (c) Gracias, V.; Frank, K. E.; Milligan, G. L.; Aube, J. Tetrahedron 1997, 53, 16241. (d) Furness, K.; Aube, J. Org. Lett. 1999, 1, 495.

(e) Forsee, J. E.; Aube, J. J. Org. Chem. 1999, 64, 4381. (f) Smith, B. T.; Gracias, V.; Aube, J. J. Org. Chem. 2000, 65, 3771.

3. (a) Aube, J.; Milligan, G. L. J. Am. Chem. Soc. 1991, 113, 8965. (b) Milligan, G. L.; Mossman, C. J.; Aube, J. J. Am. Chem. Soc. 1995, 117, 10449. (c) Wrobleski, A.; Aube, J. J. Org. Chem. 2001, 66, 886. 
4. (a) Pearson, W. H.; Schkeryantz, J. M. Tetrahedron Lett. 1992, 33, 5291. (b) Pearson, W. H.; Walavalkar, R.; Schkeryantz, J. M.; Fang, W.-k.; Blickensdorf, J. D. J. Am. Chem. Soc. 1993, 115, 10183. (c) Pearson, W. H.; Fang, W.-k. J. Org. Chem. 1995, 60, 4960. (d) Pearson, W. H.; Hutta, D. A.; Fang, W.-k. J. Org. Chem. 2000, 65, 8326. (e) Pearson, W. H.; Fang, W.-k. J. Org. Chem. 2000, 65, 7158.

5. (a) Wrobleski, A.; Sahasrabudhe, K.; Aube, J. J. Am. Chem. Soc. 2002, 124, 9974. (b) Golden, J. E.; Aube, J. Angew. Chem. Int. Ed. 2002, 41, 4316. (c) Iyengar, R.; Schildknegt, K.; Aube, J. Org. Lett. 2000, 2, 1625. (d) Aube, J.; Rafferty, P. S.; Milligan, G. L. Heterocycles 1993, 35, 1141. (e) Smith, B. T.; Wendt, J. A.; Aube, J. Org. Lett. 2002, 4, 2577.

6. Boyer, J.H. J. Am. Chem. Soc. 1951, 73, 5248.

7. (a) Davies, A. J.; Donald A. S. R.; Marks, R. E. J. Chem. Soc. (C) 1967, 2109. (b) Awad, W. I.; Fahmy, A. F. M. Can. J. Chem. 1968, 46, 2207.

8. Donald A. S. R.; Marks, R. E. J. Chem. Soc. (C) 1967, 1188.

9. Sheehy, A. Ph.D. Thesis, The National University of Ireland, 1990.

10. Black, T. H. Org. Prep. Proced. Int. 1989, 21, 179.

11. Linn, B. O.; Hauser, C. R. J. Am. Chem. Soc. 1956, 78, 6066.

12. Hauser, C. R.; Ringler, B. I.; Swamer, F. W.; Thompson, D. F. J. Am. Chem. Soc. 1947, 69, 2649.

13. (a) Beck, A. K.; Hoekstra, M. S.; Seebach, D. Tetrahedron Lett. 1977, 1187. (b) Wiles, C.; Watts, P.; Haswell, S. J.; Pombo-Villar, E. Tetrahedron Lett. 2002, 43, 2945.

14. (a) Tang, Q.; Sen, S. E. Tetrahedron Lett. 1998, 39, 2249. (b) Katritzky, A. R.; Pastor, A. J. Org. Chem. 2000, 65, 3679.

15. House, H.O. Modern Synthetic Reactions, W.A. Benjamin: New York, 2nd Edn. 1972.

16. Clark, J. H.; Miller, J. M. J. Chem. Soc., Perkin Trans 1 1977, 1743.

17. (a) Parker, W.; Raphael, R. A; Wilkinson, D. I. J. Chem. Soc., 1958, 3871. (b) Light, R. J.; Hauser, C. R. J. Org. Chem., 1961, 26, 1716. (c) Gelin, S.; Gelin, R. Bull. Soc. Chim. Fr. 1968, 1383. (d) Bestmann, H.-J.; Saalfrank, R. W. Chem. Ber. 1976, 109, 403.

18. (a) Schechter, H.; Kirk, J.C. J. Am. Chem. Soc. 1951, 73, 3087. (b) Conley, R. T. J. Org. Chem. 1958, 23, 1330.

19. (a) Pearson, W. H.; Fang, W. K. Israel J. Chem. 1997, 37, 39. (b) Lopez, F. J.; Nitzan, D. Tetrahedron Lett. 1999, 40, 2071. (c) Desai, P.; Schildknegt, K.; Agrios, K. A.; Mossman, C.; Milligan, G. L.; Aube, J. J. Am. Chem. Soc. 2000, 122, 7226.

20. (a) Mizoguchi, T. Chem. Pharm. Bull. 1962, 366. (b) Mizoguchi, T. JP 5494641961 (Chem. Abstr. 1964, 61, 10664).

21. Pilli, R. A.; Ferreira de Oliveira, M. C. Nat. Prod. Rep. 2000, 17, 117.

22. Garraffo, H. M.; Jain, P.; Spande, T. F.; Daly, J. W.; Jones, T. H.; Smith, L. J.; Zottig, V. E. J. Nat. Prod. 2001, 64, 421.

23. Beal, L. M.; Liu, B.; Chu, W. H.; Moeller, K. D. Tetrahedron 2000, 56, 10113. 
24. Robl, J. A.; Cimarusti, M. P.; Simpkins, L. M.; Brown, B.; Ryono, D. E.; Bird, J. E.; Asaad, M. M.; Schaeffer, T. R.; Trippodo, N. C. J. Med. Chem. 1996, 39, 494.

25. Sestelo, J. P.; Real, M. M.; Sarandeses, L. A. J. Org. Chem. 2001, 66, 1395. 